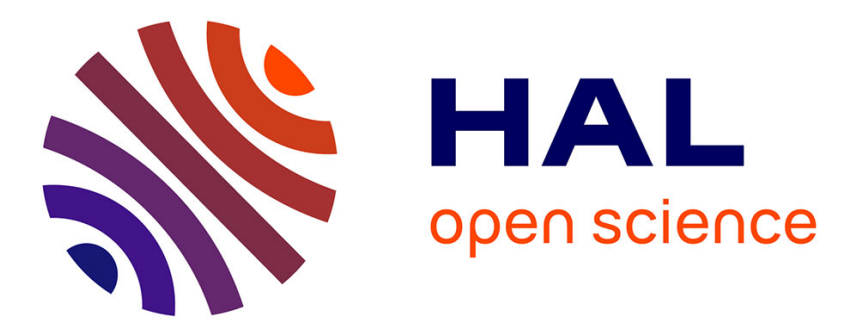

\title{
Application and validation of the clean-up tandem assay column for the screening of ochratoxin A in cocoa powder
}

Marieke Lobeau, Sarah de Saeger, Liberty Sibanda, Ildiko Barna-Vetró, Carlos van Peteghem

\section{To cite this version:}

Marieke Lobeau, Sarah de Saeger, Liberty Sibanda, Ildiko Barna-Vetró, Carlos van Peteghem. Application and validation of the clean-up tandem assay column for the screening of ochratoxin A in cocoa powder. Food Additives and Contaminants, 2007, 24 (04), pp.398-405. 10.1080/02652030601053162. hal-00577283

\section{HAL Id: hal-00577283 \\ https://hal.science/hal-00577283}

Submitted on 17 Mar 2011

HAL is a multi-disciplinary open access archive for the deposit and dissemination of scientific research documents, whether they are published or not. The documents may come from teaching and research institutions in France or abroad, or from public or private research centers.
L'archive ouverte pluridisciplinaire HAL, est destinée au dépôt et à la diffusion de documents scientifiques de niveau recherche, publiés ou non, émanant des établissements d'enseignement et de recherche français ou étrangers, des laboratoires publics ou privés. 


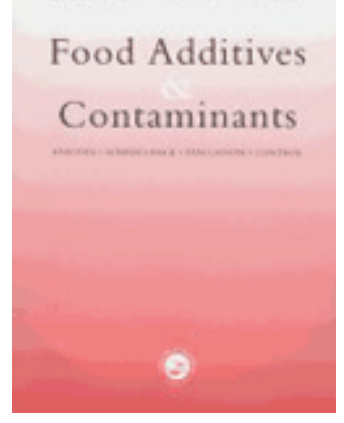

\section{Application and validation of the clean-up tandem assay column for the screening of ochratoxin A in cocoa powder}

\begin{tabular}{|r|l|}
\hline Journal: & Food Additives and Contaminants \\
\hline Manuscript ID: & TFAC-2006-173.R1 \\
\hline Manuscript Type: & Review \\
\hline Author: & $18-$ Sep-2006 \\
\hline Complete List of Authors: & $\begin{array}{l}\text { Lobeau, Marieke; Ghent University, Faculty of Pharmaceutical } \\
\text { Sciences, Laboratory of Food Analysis } \\
\text { De Saeger, Sarah; Ghent University, Faculty of Pharmaceutical } \\
\text { Sciences, Laboratory of Food Analysis } \\
\text { Sibanda, Liberty; TOXI-TEST NV } \\
\text { Barna-Vetró, Ildiko; Agricultural Biotechnology Center, Diagnostic } \\
\text { Laboratory } \\
\text { Van Peteghem, Carlos; Ghent University, Faculty of Pharmaceutical } \\
\text { Sciences, Laboratory of Food Analysis }\end{array}$ \\
\hline Methods/Techniques: & Clean-up, Extraction, Immunoassays, Screening - immunoassays \\
\hline Additives/Contaminants: & Mycotoxins - ochratoxin A \\
\hline Food Types: & Cocoa \\
\hline & \\
\hline
\end{tabular}

\section{SCHOLARONE" Manuscripts}




\title{
Application and validation of a clean-up tandem assay column for the screening of ochratoxin A in cocoa powder
}

\begin{abstract}
5 A rapid antibody-based assay for the detection of ochratoxin A in cocoa powder is described, involving sequential clean-up and visual detection of the toxin ('clean-up tandem assay column'). The screening test was developed to have a cut-off level of $2 \mu \mathrm{g}$ $\mathrm{kg}^{-1}$ and was shown to have false positive and false negative rates of $10 \%$ and $2 \%$ respectively. The analysis of six samples can be carried out in the field in approximately

$1030 \mathrm{~min}$ by untrained workers. Ten retail cocoa powders were all found not to contain detectable ochratoxin $\mathrm{A}\left(<2 \mu \mathrm{g} \mathrm{kg}^{-1}\right)$ by the proposed rapid screening test. These samples were also found to be negative $\left(<2 \mu \mathrm{g} \mathrm{kg}^{-1}\right)$ when analysed using an LC-MS/MS method.
\end{abstract}

Keywords : ochratoxin A, cocoa powder, immunoassay, qualitative test, validation 


\section{Introduction}

Consumption of cocoa powder can contribute to the intake of the mycotoxin ochratoxin A (OTA). In cocoa beans OTA is most notably produced by Aspergillus carbonarius and Penicillium verrucosum at a minimum water activity of 0.85 . OTA is mainly formed in the initial stages of sun drying. The drying period is critical to avoid the appearance of

20 OTA in cocoa beans, rather than the storage period (Bucheli et al. 2000).

There is no doubt that prevention of contamination at the source is the best procedure for controlling the contamination. However, despite improvements in production and storage techniques and current scientific and technical knowledge, it is not possible to entirely

25 eliminate these moulds and consequently eliminate OTA from food. Therefore, tight EC limits are set for ochratoxin A (Commission Regulation (EC) No. 123/2005 of 26 January 2005 ) for a variety of food products ranging from $2-10 \mu \mathrm{g} \mathrm{kg}^{-1}$. For cocoa and chocolate regulatory limits are still under discussion, the most likely limits will be in the range 1-2 $\mu \mathrm{g} \mathrm{kg}^{-1}$ for raw cocoa materials and finished products respectively (Serra Bonhevi 2004).

Few conventional methods have been published for OTA determination in cocoa beans (Hurst and Martin 1983, 1998, Serra Bonhevi 2004, Amézqueta et al. 2004) and cocoaderived products (Burdaspal and Legarda 2003, Brera et al. 2003). Clean-up of extract solutions using immunoaffinity columns (IAC) combined with high performance liquid

35 chromatography (HPLC) provides sensitive and selective results, but are laborious, timeconsuming, require sophisticated equipment and cannot be used in situ. 
Most commercial test kits for OTA make use of ELISA-methods (http://www.aoac.org/testkits/kits-toxins.htm). Other rapid assays for OTA detection 40 described in literature are array biosensors, fluorescence polarisation immunoassays, screen printed electrode immunoassays, surface plasmon resonance biosensors, quartz crystal microbalance biosensors (Visconti and De Girolamo 2005). Only few on-site rapid assays that can be used without special laboratory equipment are available (lateral flow devices, membrane-based flow-through portable immunoassays, test cards)

45 (Dietrich et al. 1995, De Saeger and Van Peteghem 1999, Danks et al. 2003, Zheng et al. 2005, Saha et al. 2006). However, application of methods with visual detection is difficult for intensively coloured products such as cocoa powder. There are no commercial on-site tests for this food matrix. Therefore, we developed a home-made clean-up tandem assay column (patent application pending (Sibanda et al. 2001)), for the rapid detection of OTA

50 in cocoa powder. In this column, clean-up and detection are performed in one step enabling visual evaluation.

\section{Materials and methods}

\section{Reagents and materials}

55 OTA standard, casein sodium salt (casein), Tween 20 and tetramethoxysilane were purchased from Sigma Chemical Co (Bornem, Belgium). Rabbit anti-mouse immunoglobulins (IgG) (protein concentration: 2,7 $\mathrm{g}^{-1}$ ) were supplied by DakoCytomation (Heverlee, Belgium). CNBr-activated Sepharose 4B was purchased from Amersham Biosciences $\mathrm{AB}$ (Uppsala, Sweden). $\mathrm{NH}_{2}$-derived silica (Bio-Sil $\mathrm{NH}_{2}$, 
60 diameter $0.040 \mathrm{~mm}$ ), Bond Elut SAX-columns, Bond Elut Si-columns, tubes (Bond Elut reservoir, $1 \mathrm{ml}$ ) and polyethylene frits (1/4 in. diameter) were supplied by Varian Belgium NV/SA (Sint-Katelijne-Waver, Belgium). Bakerbond ${ }^{\mathrm{TM}} \mathrm{SPE} \mathrm{C}_{18}$-columns were purchased from JT Baker B.V. (Deventer, Holland). OchraTest ${ }^{\mathrm{TM}}$ immunoaffinity columns were supplied by Vicam (Watertown, MA).

65

OTA-horse radish peroxidase (HRP)-conjugate was prepared by the Agricultural Biotechnology Center, Diagnostic Laboratory, Gödöllö, Hungary. Monoclonal antibodies against OTA were produced and characterized by the same Institute. The antibody was an IgG1 with kappa light chains with a $9.3 \%$ cross-reaction with ochratoxin B but none at all 70 with ochratoxin $\alpha$, coumarin, 4-hydroxycoumarin and D,L-phenylalanine (GyöngyösiHorváth et al. 1996). Phosphate buffered saline (PBS) $0.01 \mathrm{M}, \mathrm{pH} 7.4$, was used to prepare the wash solution (PBS-Tween 0.05\%) and the assay buffer (PBS-casein 0.1\%). Proclin 300 (5-chloro-2-methyl-4-isothiazolin-3-one and 2-methyl-4-isothiazolin-3-one) was purchased from Supelco (Bellefonte, PA, USA) and was added to the buffers as an 75 antimicrobial preservative. Methanol was HPLC-grade and water was obtained from a Milli-Q Gradient System (Millipore, Brussels, Belgium). The substrate chromogen solution used was Colorburst ${ }^{\mathrm{TM}}$ Blue $\mathrm{TMB} /$ Peroxide (ALerCHEK, Inc. USA). Stock solutions of OTA $\left(1 \mathrm{mg} \mathrm{ml}^{-1}\right)$ and working solutions (100 ng $\mu \mathrm{l}^{-1}, 10 \mathrm{ng} \mu \mathrm{l}^{-1}, 1 \mathrm{ng} \mu \mathrm{l}^{-1}$ ) were prepared in methanol and stored at $-20^{\circ} \mathrm{C}$. Ederol filters No. $14,110 \mathrm{~mm}$ were 80 purchased from Binzer \& Munktell Filter GmbH (Battenberg, Germany). 


\section{Blank cocoa powder sample}

The OTA concentration in a commercially available cocoa powder sample, which was intended to be used for the development of the clean-up tandem assay column, was 85 determined using a liquid chromatography tandem mass spectrometry (LC-MS/MS) method with immunoaffinity clean-up.

Extraction of the cocoa powder sample $(20 \mathrm{~g})$ was carried out by adding $50.0 \mathrm{ml}$ $\mathrm{MeOH} / 3 \% \mathrm{NaHCO}_{3}(80 / 20, \mathrm{v} / \mathrm{v})$ to the sample and by shaking for $30 \mathrm{~min}$ at \pm 250

90 revolutions per min (rpm) with an Orbital Shaker SO3 (Stuart Scientic, UK). The extract was centrifuged for $10 \mathrm{~min}(3600 \mathrm{rpm})$. The supernatant $(10.0 \mathrm{ml})$ was diluted with 40.0 ml PBS-buffer. This solution $(50.0 \mathrm{ml})$ was filtered through an Ederol filter and passed through the OchraTest ${ }^{\mathrm{TM}}$ column at the rate of gravity. The column was washed with 5.0 $\mathrm{ml}$ water (under gravity). OTA was eluted with $3.0 \mathrm{ml} \mathrm{MeOH}$. The eluate was evaporated

95 to dryness under a $\mathrm{N}_{2}$ stream and re-dissolved with $300 \mu$ l mobile phase for the LCMS/MS analysis.

A Waters Alliance 2695 XE high performance liquid chromatography (HPLC) system coupled to a Micromass Quatro micro triple quadrupole mass spectrometer was used

100 (Waters, Milford, MA, USA). The analytical column was an Alltima $\mathrm{C}_{18}, 5 \mu \mathrm{m}, 150 \times 3.2$ mm (Alltech Associates, Deerfield, IL, USA), while the guard column was an Alltima $\mathrm{C}_{18}, 5 \mu \mathrm{m}, 7.5 \times 3.2 \mathrm{~mm}$ (Alltech Associates, Deerfield, IL, USA). Injection volume was $20 \mu 1$. The mobile phase consisted of variable mixtures of formic acid in acetonitrile $(0.3 \%$, solvent $\mathrm{A})$ and formic acid in water $(0.3 \%$, solvent $\mathrm{B})$ at a flow of $0.3 \mathrm{ml} \mathrm{min} \mathrm{m}^{-1}$. 
105 The gradient elution programme was: isocratic conditions with $10 \%$ A: $90 \%$ B for 3 min, linear gradient from 10 to $100 \%$ A for 6.5 min and isocratic conditions with $100 \%$ A for 4.5 min. Then, within $1 \mathrm{~min}$, the concentration of A was brought back to $10 \%$. This was maintained for $15 \mathrm{~min}$. The mass spectrometer was operated in the positive electrospray ionisation (ESI+) mode using multiple reaction monitoring (MRM). Capillary voltage

110 was $3.7 \mathrm{kV}$ and nitrogen was used as spray gas. Source and desolvation temperatures were set at 120 and $350^{\circ} \mathrm{C}$, respectively. The precursor ion was $\mathrm{m} / \mathrm{z} 404$. The cone voltage was $35 \mathrm{~V}$. Product ions and collision energy were determined. Collision gas was argon. For OTA product ions were at m/z 239 (collision energy $24 \mathrm{eV}$ ) and m/z 341 (collision energy $20 \mathrm{eV}$ ).

115

Extraction solution

The optimal composition of the extraction solution which will be used for the clean-up tandem assay procedure was determined by high performance liquid chromatography (HPLC) coupled to fluorescence detection (FLD). Blank cocoa powder samples (5 g) 120 were fortified $\left(5 \mu \mathrm{g} \mathrm{kg}^{-1}, 15 \mu \mathrm{g} \mathrm{kg}^{-1}\right.$ and $25 \mu \mathrm{g} \mathrm{kg}^{-1}, \mathrm{n}=3$ for each concentration level) with OTA the night before using the afore mentioned working solutions in $\mathrm{MeOH}$. They were extracted with $15 \mathrm{ml}$ of different ratios $(100 / 0,95 / 5,90 / 10,80 / 20,75 / 25,50 / 50$, v/v) of a $\mathrm{MeOH} / 3 \% \mathrm{NaHCO}_{3}(\mathrm{v} / \mathrm{v}$ ) solution (Lobeau et al. 2005) by shaking for 5 minutes at $\pm 200 \mathrm{rpm}$ with an Orbital Shaker SO3 (Stuart Scientic, UK). The suspension 125 was filtered through an Ederol filter and the filtrate was analysed by HPLC-FLD. 
Sample extracts $(50 \mu \mathrm{l})$ were injected with an autosampler and separated on a Supelco Discovery $\mathrm{C}_{18}(5 \mu \mathrm{m}, 25 \mathrm{~cm}$ x $4.6 \mathrm{~mm})$ column (Supelco, Bellefonte, PA, USA) at room temperature. The mobile phase used was acetonitrile/water/acetic acid (54/44/2) at a flow 130 rate of $1 \mathrm{ml} \mathrm{min}^{-1}$. The HPLC system consisted of a Waters 600 Controller, a Waters 610 Fluid Unit and a Waters 474 scanning fluorescence detector (333 nm excitation wavelength, $470 \mathrm{~nm}$ emission wavelength). Sample OTA concentrations were quantified by comparing sample peak areas to those of standards and extraction recoveries were determined.

135

\section{Clean-up tandem assay column: Clean-up layer}

Various solid-phase materials (aminopropyl-derived silica $\left(\mathrm{NH}_{2}\right.$-derived silica), octadecyl-derived silica, silica (silanol groups), Strong Anion Exchange-silica (SAX)) were evaluated as to their ability to adsorb the brown colour and other matrix

140 interferences (Sibanda et al. 2002b), while at the same time allowing OTA to elute directly.

Blank cocoa powder samples (5 g) were fortified $\left(20 \mu \mathrm{g} \mathrm{kg}^{-1}, 40 \mu \mathrm{g} \mathrm{kg}^{-1}, 80 \mu \mathrm{g} \mathrm{kg}^{-1}\right.$ and $160 \mu \mathrm{g} \mathrm{kg}^{-1}$ ) with OTA the night before using the afore mentioned working solutions in $145 \mathrm{MeOH}$ and extracted with $15 \mathrm{ml} \mathrm{MeOH} / 3 \% \mathrm{NaHCO}_{3}(95 / 5$, v/v) by shaking for 5 minutes at $\pm 200 \mathrm{rpm}$ with an Orbital Shaker SO3 (Stuart Scientic, UK). The suspension was filtered through an Ederol filter. 
The filtrate was diluted in order to reduce the methanol concentration. This avoids the

150 denaturation of the antibodies in the clean-up tandem assay column. Milli-Q water and a 3\% $\mathrm{NaHCO}_{3}$ solution (Sibanda et al. 2002a) were evaluated as dilution solutions by comparing the partition coefficients $\left(\mathrm{K}_{\mathrm{d}}\right)$ for the dispersion of OTA between the selected solid phase (i.e. $\mathrm{NH}_{2}$-derived silica, see Results: Clean-up layer) and the $\mathrm{MeOH} / 3 \%$ $\mathrm{NaHCO}_{3}(95 / 5, \mathrm{v} / \mathrm{v})$ mobile phase. The filtrate $(1.5 \mathrm{ml})$ was diluted with $2.1 \mathrm{ml}$ Milli-Q

155 water or with $2.1 \mathrm{ml}$ of a $3 \% \mathrm{NaHCO}_{3}$ solution. This dilution was extracted over $200 \mathrm{mg}$ of $\mathrm{NH}_{2}$-derived silica without application of pressure (Lobeau et al. 2005). The eluate from the column was collected and the OTA concentration was measured by HPLC-FLD. The second fraction, obtained by washing the column with $4 \mathrm{ml}$ of $\mathrm{MeOH}$, was evaporated to dryness and redissolved in $300 \mu \mathrm{l}$ of the mobile phase for HPLC analysis.

160 The partition coefficient $\left(\mathrm{K}_{\mathrm{d}}\right)$ was calculated using the formula $\mathrm{K}_{\mathrm{d}}=$ [OTA wash fraction]/[OTA frontal elution fraction] or $\mathrm{K}_{\mathrm{d}}=$ [OTA solid phase]/[OTA mobile phase].

\section{Clean-up tandem assay column: detection layer Sepharose gel}

The secondary rabbit anti-mouse antibodies were coupled to the Sepharose gel following

165 the principles and methods of Pharmacia LKB Biotechnology (Pharmacia LKB Biotechnology 1993, Lobeau et al. 2005).

\section{Clean-up tandem assay column: detection layer sol-gel}

Encapsulation of the monoclonal mouse anti-OTA-antibody was carried out according to

170 Zühlke et al. 1995. Hydrochloric acid (0.4 $\mathrm{ml}$ of $0.04 \mathrm{M})$, Milli-Q water (1.5 ml) and 6.8 $\mathrm{ml}$ tetramethoxysilane (TMOS) were mixed and sonicated under ice-cooling for $30 \mathrm{~min}$. 
This silica sol $(1 \mathrm{ml})$ was added to $1 \mathrm{ml}$ of ice-cooled PBS pH 7.6 containing the amount of the antibodies to be immobilised (10 $\mu \mathrm{l}$ of $2 \mathrm{mg} \mathrm{ml}^{-1}$ primary anti-OTA antibody) in a beaker. The gel was weighed and the beaker was stored at $4{ }^{\circ} \mathrm{C}$ without capping. The 175 drying process was stopped after 20 hours incubation resulting in a clear glass. After a weight loss of $\pm 30 \%$, the glass was ground in a mortar and packed into a column. The sol-gel glass immunoadsorber was then stored in PBS at $4^{\circ} \mathrm{C}$.

\section{Preparation of the clean-up tandem assay column}

180 A polyethylene frit (grid) was first put in the $1 \mathrm{ml}$ tube, followed by the addition of 200 $\mu 1$ of the detection layer Sepharose gel suspended in PBS or $50 \mathrm{mg}$ of sol-gel powder. Another grid separated the detection layer and $200 \mathrm{mg}$ clean-up layer above. A third grid was placed above the clean-up layer (Lobeau et al. 2005).

\section{Clean-up tandem assay procedure}

The clean-up tandem assay procedure was the same as mentioned in Lobeau et al. 2005. In the clean-up tandem assay, each reagent was applied in sequence at the inlet or at the outlet means of the tube at a rate of $\pm 1 \mathrm{drop} / \mathrm{s}$. These reagents were respectively primary mouse anti-OTA antibodies $(100 \mu \mathrm{l})$, wash solution $(3 \mathrm{ml})$, diluted sample extract $(3.6$

$190 \mathrm{ml})$, wash solution $(3 \mathrm{ml})$, OTA-HRP conjugate $(200 \mu \mathrm{l})$, wash solution $(3 \mathrm{ml})$, colour substrate $(50 \mu \mathrm{l})$ (see: Reagents and Materials). For columns filled with sol-gel powder, the application of the diluted cocoa powder extract $(3.6 \mathrm{ml})$ onto the column was the first step. 
195 The test was developed to have a visual cut-off level of $2 \mu \mathrm{g}$ OTA kg${ }^{-1}$ cocoa powder (EC proposed limit for cocoa powder) by optimising the dilutions of the primary mouse antiOTA antibodies and the OTA-HRP conjugate. In this way the absence of a developed blue colour indicated a positive result with an OTA content above $2 \mu \mathrm{g} \mathrm{kg}^{-1}$.

\section{OTA analysis of 10 different commercial cocoa powder samples}

Ten cocoa powder samples commercially available on the Belgian market were analysed in triplicate using the clean-up tandem assay column. The results were compared with these using the above mentioned LC-MS/MS method with immunoaffinity clean-up.

\section{Results and discussion}

Blank cocoa powder sample

The OTA concentration in the tested cocoa powder sample was found to be less than 0.1 $\mu \mathrm{gg}^{-1}\left(0.0955 \mu \mathrm{g} \mathrm{kg}^{-1}\right)$ with the LC-MS/MS method. The clean-up tandem assay column was further developed with this essentially-blank sample.

210

\section{Extraction solution}

Lobeau et al. 2005 used $\mathrm{MeOH} / 3 \% \mathrm{NaHCO}_{3}(80 / 20$, v/v) as solvent for the extraction of OTA from roasted coffee. For OTA extraction from cocoa powder different ratios of $\mathrm{MeOH} / 3 \% \mathrm{NaHCO}_{3}(\mathrm{v} / \mathrm{v})$ were examined and recoveries were determined using the 215 described HPLC-FLD method. Large amounts of $3 \% \mathrm{NaHCO}_{3}$ in the extraction solution resulted in dark filtrates. Less than $20 \%$ of a $3 \% \mathrm{NaHCO}_{3}$ solution was necessary to avoid 
this interfering coloration. The best recovery $(100.2 \pm 7.1 \%)$ was found with $\mathrm{MeOH} / 3 \%$ $\mathrm{NaHCO}_{3}(95 / 5, \mathrm{v} / \mathrm{v})$

220 Clean-up layer

Only SAX-silica and $\mathrm{NH}_{2}$-derived silica were found to be able to adsorb most of the colour of the cocoa powder. Recoveries were comparable for both. $\mathrm{NH}_{2}$-derived silica was chosen because of the easier availability.

225 Dilution of the methanolic filtrate was necessary to avoid denaturation of the antibodies in the column. Milli-Q water and a $3 \% \mathrm{NaHCO}_{3}$ solution were tested as dilution solvent and compared by calculating the partition coefficients $\left(\mathrm{K}_{\mathrm{d}}\right)$ for the dispersion of OTA between the $\mathrm{NH}_{2}$-derived silica solid phase and the $\mathrm{MeOH} / 3 \% \mathrm{NaHCO}_{3}(95 / 5, \mathrm{v} / \mathrm{v})$ mobile phase. OTA should elute directly to the detection layer, so, the partition 230 coefficient should be as low as possible.

Partition coefficients are shown in Table I. On average lower coefficients $\left(\mathrm{K}_{\mathrm{d}}=0.4828 \pm\right.$ 0.086) were obtained using $3 \% \mathrm{NaHCO}_{3}$ than with Milli-Q water $\left(\mathrm{K}_{\mathrm{d}}=0.9806 \pm 0.488\right.$. Therefore, $1.5 \mathrm{ml}$ of the sample extraction filtrate was diluted with $2.1 \mathrm{ml}$ of a $3 \%$ $235 \mathrm{NaHCO}_{3}$ solution (Lobeau et al. 2005). This was a reduction of the $\mathrm{MeOH}$ content to \pm $40 \%$.

"[Insert Table I about here]"

Clean-up tandem assay column set-up 
240 The reason for binding secondary rabbit anti-mouse antibodies to the Sepharose gel was that direct binding of the capture protein (the primary monoclonal anti-OTA antibody) gave no binding results probably due to conformational changes that reduced the antiOTA antibody's affinity for the analyte (Wild 2001, Cichna et al. 2001).

245 In most cases the immobilisation reaction can only be applied using highly purified ligands and often leads to conformational changes of bioligands and therefore decreases the affinity for the analyte. This problem can be avoided when ligands are immobilised in the pores of a sol-gel glass matrix (Cichna et al. 2001). This method was compared with the Sepharose method. The preparation of the sol-gel was found to be less labour 250 intensive than the Sepharose method. However, to apply it as a gel in the clean-up tandem assay column, it was not found to be applicable. The colour substrate seemed to react non-specifically with polar silane groups in the gel and colour development immediately appeared only on the side where the substrate made the initial contact with the gel. This result was observed for both negative and positive samples.

255

An example of a serial of results for the clean-up tandem assay column using Sepharose gel is given in Figure 1. The dilution of the primary mouse anti-OTA antibodies and the OTA-HRP conjugate were respectively $1 / 300$ and 1/500 in assay buffer. The intensity of the colour development decreased with increasing concentrations of OTA. No blue colour 260 developed at a concentration of $2 \mu \mathrm{g} \mathrm{kg}^{-1}$. Therefore, this was the cut-off level of the assay.

“[Insert Figure 1 about here]" 
The analysis of six samples can be carried out in the field in approximately 30 min by untrained workers.

Dilution of the filtrate with $3 \% \mathrm{NaHCO}_{3}$ resulted after a few min in precipitation and gelation of the proteins in the cocoa powder due to the alkaline $\mathrm{pH}$. Because this could compromise the flow of the sample through the column, dilution with Milli-Q water was

270 found to be more appropriate, contrary to the results obtained in Results: Clean-up layer.

\section{Validation of the clean-up tandem assay method using fortified cocoa powder samples}

An intra-laboratory validation was performed with blank cocoa powder samples fortified at $0,1,2,3,4$ and $5 \mu \mathrm{g}$ OTA $\mathrm{kg}^{-1}$ the night before using the afore mentioned working

275 solutions in $\mathrm{MeOH}$. The following performance characteristics were determined: precision (in terms of false positive and false negative results), sensitivity, specificity, positive and negative predictive values and unreliability region (Trullols et al. 2004a, Trullols et al. 2004b).

280 For this qualitative screening test, precision was expressed as the number of false positive and false negative results as can be seen in Table II. Based on these results, the sensitivity i.e. the ability to detect a true positive result, and the specificity i.e. the ability to detect a true negative result, were respectively 98 and $90 \%$. The predictive value of positive results i.e. fraction of positive results that are true positives, was $93 \%$ and the predictive value of negative results i.e. fraction of negative results that are true negatives, was $97 \%$. The unreliability region, the region in which false results were obtained, was between 1 
and $2 \mu \mathrm{g} \mathrm{kg}^{-1}$. These results are shown in Table III. For mycotoxins criteria for screening methods are not available but according to Commission Decision 2002/657/EC the requirement for a screening method is the following: only those analytical techniques, for

290 which it can be demonstrated in a documented traceable manner that they are validated and have a false compliant rate of $<5 \%$ at the level of interest shall be used for screening purposes. In case of a suspected non-compliant result, this result shall be confirmed by a confirmatory method.

“[Insert Tables II and III about here]“"

295

\section{Performance characteristic curve}

Performance characteristics were also estimated by a curve (Trullols et al. 2004b). Blank cocoa powder samples were fortified at $0,0.5,1,1.5,2,3,4$ and $5 \mu \mathrm{g}$ OTA $\mathrm{kg}^{-1}$ the night before using the afore mentioned working solutions in $\mathrm{MeOH}$. At each concentration

300 level, the percentage of positives, $\mathrm{P}(\mathrm{X})$ and the percentage of negatives, $\mathrm{N}(\mathrm{X})$ was calculated. With these data, a graph of positives' percentage versus the concentration levels tested was plotted. The performance characteristic curve was obtained by fitting the experimental results from Table IV to a sigmoidal function that minimized the root mean square of the residuals (Figure 2). To obtain the performance parameters, the 305 probabilities of committing false-positive $(\alpha)$ and false-negative $(\beta)$ errors that could be accepted had to be fixed. Usually, these values are fixed at $5 \%$ and correspond to the horizontal lines plotted on Figure $2, \alpha=5 \%$ and $100-\beta=95 \%$ (Commission Decision 657/2002). Once the probabilities of error were fixed, all performance parameters were calculated. This was possible using the equation of the sigmoidal curve: 
$310 \quad \mathrm{y}=\mathrm{y}_{0}+\left(\mathrm{a} /\left(1+\mathrm{e}^{-(\mathrm{x}-\mathrm{x} 0) / \mathrm{b}}\right)\right)$ with:

$\mathrm{a}=100.4838, \mathrm{~b}=0.2642, \mathrm{x}_{0}=1.3449, \mathrm{y}_{0}=-1.0662$

"[Insert Table IV and Figure 2 about here]"

315 The unreliability region was defined by its upper and lower limits. The upper limit corresponded to the concentration at which the $100-\beta$ line crossed the $\mathrm{P}(\mathrm{X})$ curve $(2.16$ $\mu \mathrm{g} \mathrm{kg}^{-1}$ ). Therefore, $2.2 \mu \mathrm{g} \mathrm{kg}^{-1}$ was the cut-off as well as the detection limit of our assay, corresponding to the one visually observed. The lower limit corresponded to the concentration at which the $\alpha$ line crossed the $\mathrm{P}(\mathrm{X})$ curve $\left(0.62 \mu \mathrm{g} \mathrm{kg}{ }^{-1}\right)$. Therefore the 320 unreliability region was between 0.6 and $2.2 \mu \mathrm{g} \mathrm{kg}^{-1}$. The sensitivity rate at $2.2 \mu \mathrm{g} \mathrm{kg}^{-1}$ was equal to $95 \%$, as it corresponded to the point where $P(X)=100-\beta$. The false negative rate at $2.2 \mu \mathrm{g} \mathrm{kg}^{-1}$ was equal to $5 \%$ as $\mathrm{fn}=100-\mathrm{P}(\mathrm{X})$. Similarly, the specificity rate at 0.6 $\mu \mathrm{gg}^{-1}$ was equal to $95 \%$, as it corresponded to the point where $\mathrm{N}(\mathrm{X})=100-\mathrm{P}(\mathrm{X})$. The false positive rate at this concentration level was also $5 \%$ because $\mathrm{fp}=\mathrm{P}(\mathrm{X})$. Gel 325 preparation was probably a source of error and gave the false negative result at the $3 \mu \mathrm{g}$ $\mathrm{kg}^{-1}$ concentration level. Preparing the gel in larger volumes would favour the repeatability and minimize false negative results.

\section{OTA analysis of 10 different commercial cocoa powder samples}

330 All ten commercially available cocoa powder samples were found to be negative (less than $2 \mu \mathrm{g} \mathrm{kg}^{-1}$ ) using the clean-up tandem assay column. These qualitative results were 
compared with the quantitative results obtained using the above mentioned LC-MS/MS method. Results are shown in Table V.

335 "[Insert Table V about here]"

\section{Conclusion}

A clean-up tandem assay column for the detection of OTA in cocoa powder was developed and the method was validated by the determination of its qualitative 340 performance parameters. The column comprised two superposed layers; clean-up and detection were performed on one single column device. The result of the assay can be binary only: yes/no response indicating whether OTA is present or not above the cut-off level. The test was calibrated to a cut-off level of $2 \mu \mathrm{g}$ OTA $\mathrm{kg}^{-1}$ cocoa powder. Establishing this parameter by means of a performance characteristic curve resulted in a 345 cut-off level of $2.2 \mu \mathrm{g}_{\mathrm{OTA} \mathrm{kg}}{ }^{-1}$ cocoa powder. Therefore, the described clean-up tandem assay column can be used as a rapid screening tool for OTA in cocoa powder.

\section{Acknowledgement}

This work was financially supported by Bijzonder Onderzoeksfonds (BOF) of the Ghent

350 University (011D02803) and FWO Flanders Research Project N ${ }^{\circ}$ G.0312.03.

\section{References}


Amézqueta S, González-Peňas E, Murillo M, López de Cerain A. 2004. Validation of a 355 high-performance liquid chromatography analytical method for ochratoxin A quantification in cocoa beans. Food Additives and Contaminants 21:1096-1106.

AOAC International [internet]. Available from: http://www.aoac.org/testkits/kitstoxins.htm. Accessed 2006 May 24.

360

Brera C, Grossi S, de Santis B, Miraglia M. 2003. High performance liquid chromatographic method for the determination of ochratoxin A in cocoa powder. Journal of Liquid Chromatography and Related Technologies 26:585-598.

365 Bucheli P, Kanchanomai C, Meyer I, Pittet A. 2000. Development of ochratoxin A during Robusta (Coffea canephora) coffee cherry drying. Journal of Agricultural and Food Chemistry 48:1358-1362.

Burdaspal PA, Legarda TM. 2003. Occurrence of ochratoxin A in samples of different 370 types of chocolate and cocoa powder, marketed in Spain and fifteen foreign countries. Alimentaria October:143-153.

Cichna M, Markl P, Knopp D, Niessner R. 2001. On-line coupling of sol-gel-generated immunoaffinity columns with high-performance liquid chromatography. Journal of 375 Chromatography A 919:51-58. 
Commission Decision 657/2002 of 12 August 2002 implementing Council Directive 96/23/EC concerning the performance of analytical methods and the interpretation of results. Official Journal of the European Communities L 221/8, (August 17).

380

Commission Regulation (EC) No. 123/2005 of 26 January 2005 amending Regulation (EC) No. 466/2001 as regards Ochratoxin A. Official Journal of the European Union 2005, L25:3.

385 Danks C, Ostoja-Starzewska, Flint J, Banks JN. 2003. The development of a lateral flow device for the discrimination of OTA producing and non-producing fungi. Mycotoxins in Food Production Systems. Aspects of Applied Biology 68:21-28.

De Saeger S, Van Peteghem C. 1999. Flow-through membrane-based enzyme 390 immunoassay for rapid detection of ochratoxin A in wheat. Journal of Food Protection 62:65-69.

Dietrich R, Schneider E, Usleber E, Martlbauer E. 1995. Use of monoclonal antibodies for the analysis of mycotoxins. Natural Toxins 3:288-293.

395

Gyöngyösi-Horváth Á, Barna-Vetró I, Solti L. 1996. A new monoclonal antibody detecting ochratoxin A at the picogram level. Letters in Applied Microbiology 22:103105. 
400 Hurst WJ, Martin Jr. RA. 1983. High-performance liquid chromatographic determination of ochratoxin A in artificially spiked cocoa beans. Journal of Chromatography 265:353356.

Hurst WJ, Martin Jr. RA. 1998. High-performance liquid chromatographic determination 405 of ochratoxin A in artificially contaminated cocoa beans using automated sample cleanup. Journal of Chromatography $A$ 810:89-94.

Lobeau M, De Saeger S, Sibanda L, Barna-Vetró I, Van Peteghem C. 2005. Development of a new clean-up tandem assay column for the detection of ochratoxin A in roasted 410 coffee. Analytica Chimica Acta 538:57-61.

Pharmacia LKB Biotechnology, Affinity Chromatography, Principles and Methods 1993, 24-30.

415 Saha D, Acharya D, Dhar TK. Method for homogeneous spotting of antibodies on membranes: application to the sensitive detection of ochatoxin A. Analytical and Bioanalytical Chemistry DOI: 10.1007/s00216-006-0484-4.

Serra Bonhevi J. 2004. Occurrence of ochratoxin A in cocoa products and chocolate.

420 Journal of Agricultural and Food Chemistry 52:6347-6352. 
Sibanda L, De Saeger S, Van Peteghem C. 2001. International patent application No. PCT/EP02/01496: Device and method for detecting the presence of an analyte.

425 Sibanda L, De Saeger S, Van Peteghem C. 2002a. Optimization of solid-phase clean-up prior to liquid chromatographic analysis of ochratoxin A in roasted coffee. Journal of Chromatography A 959:327-330.

Sibanda L, De Saeger S, Barna-Vetró I, Van Peteghem C. 2002b. Development of a 430 solid-phase cleanup and portable rapid flow-through enzyme immunoassay for the detection of ochratoxin A in roasted coffee. Journal of Agricultural and Food Chemistry 50:6964-6967.

Trullols E, Ruisánchez I, Rius FX. 2004a. Validation of qualitative analytical methods. 435 Trends in Analytical Chemistry 23:137-145.

Trullols E, Ruisánchez I, Rius FX. 2004b. Qualitative method for determination of aflatoxin B1 in nuts. Journal of AOAC International 87:417-423.

440 Visconti A, De Girolamo A. 2005. Fitness for purpose - Ochratoxin A analytical developments. Food Additives and Contaminants, Supplement 1:37-44.

Wild D. 2001. Introduction to immunoassay principles. In: The Immunoassay Handbook, second edition, Nature Publishing Group, New York. p. 32-33. 
445 Zheng MZ, Richard JL, Binder J. 2006. A review of rapid methods for the analysis of mycotoxins. Mycopathologia 161:261-273.

Zühlke J, Knopp D, Niessner R. 1995. Sol-gel glass as a new support matrix in immunoaffinity chromatography. Fresenius Journal of Analytical Chemistry 352:654$450 \quad 659$. 


\section{Figure captions}

455 Figure 1: Clean-up tandem assay: a serial of results: the detection layer of each column is shown and the colour can be visually evaluated. Above the detection layer a small part of the clean-up layer is visible. The OTA concentrations $\left(\mu \mathrm{g} \mathrm{kg}^{-1}\right)$ of the cocoa powder samples are mentioned below the tubes.

460 Figure 2: Experimental performance characteristic curve. Probability of positive responses, $P(X)$, were plotted versus concentration levels tested. (1) $f p=P(X)$; (2) $X_{0.05}$ where specificity $=\mathrm{N}(\mathrm{X})=100-\mathrm{P}(\mathrm{X})$; (3) $\mathrm{X}_{0.95}$, cut-off limit, detection limit; (4) fn = $100-\mathrm{P}(\mathrm{X}) ;(5)$ sensitivity $=\mathrm{P}(\mathrm{X})=100-\beta$. 
Table I. Calculated partition coefficients for the distribution of OTA between the aminopropyl solid phase and the $\mathrm{MeOH} / 3 \% \mathrm{NaHCO}_{3}(95 / 5$, v/v) mobile phase* .

\begin{tabular}{|c|c|c|c|}
\hline $\begin{array}{l}\text { OTA concentration } \\
\left(\mu \mathrm{g} \mathrm{kg}^{-1}\right)\end{array}$ & $\begin{array}{l}\text { OTA concentration } \\
\text { solid phase } \\
\left(\mu \mathrm{g} \mathrm{kg}^{-1}\right)\end{array}$ & $\begin{array}{l}\text { OTA concentration } \\
\text { mobile phase } \\
\left(\mu \mathrm{g} \mathrm{kg}^{-1}\right)\end{array}$ & $\begin{array}{l}\text { Partition coefficient } \\
\left(\mathrm{K}_{\mathrm{d}}=\text { solid/mobile }\right)\end{array}$ \\
\hline $\begin{array}{l}\text { dilution with a } 3 \% \\
\mathrm{NaHCO}_{3} \text { solution }\end{array}$ & 8 & & \\
\hline 20 & 3.99 & 6.68 & 0.5974 \\
\hline 40 & 8.40 & 18.41 & 0.4563 \\
\hline 80 & 18.23 & 46.55 & 0.3915 \\
\hline 160 & 44.93 & 92.43 & 0.4861 \\
\hline average & & & $0.4828 \pm 0.086$ \\
\hline $\begin{array}{c}\text { dilution with Milli-Q } \\
\text { water }\end{array}$ & & & \\
\hline 20 & 2.79 & 7.34 & 0.3806 \\
\hline 40 & 10.15 & 11.92 & 0.8519 \\
\hline 80 & 28.07 & 18.30 & 1.534 \\
\hline 160 & 42.54 & 36.80 & 1.156 \\
\hline average & & & $0.9806 \pm 0.488$ \\
\hline
\end{tabular}


Table II. Contingency table with numerical values as performed with the clean-up tandem assay column for the detection of ochratoxin A in cocoa powder.

\begin{tabular}{|c|c|c|c|}
\hline & $\begin{array}{c}\text { Samples fortified at } 2 \mu \mathrm{g} \mathrm{kg}^{-1} \\
\text { OTA or more }\end{array}$ & $\begin{array}{l}\text { Samples fortified at less } \\
\text { than } 2 \mu \mathrm{g} \mathrm{kg}^{-1} \text { OTA }\end{array}$ & Total \\
\hline $\begin{array}{l}\text { Positive } \\
\text { (no colour ) }\end{array}$ & $55\left(\mathrm{tp}^{*}\right)$ & $4\left(\mathrm{fp}^{\dagger}\right)$ & 59 \\
\hline $\begin{array}{l}\text { Negative } \\
\text { (blue colour) }\end{array}$ & $1\left(\mathrm{fn}^{\dagger}\right)$ & $36\left(\operatorname{tn}^{\mathrm{q}}\right)$ & 37 \\
\hline Total & 56 & 40 & $96\left(\mathrm{~N}^{\S}\right)$ \\
\hline
\end{tabular}


1 4 5

Table III. Qualitative performance parameters for the detection of ochratoxin A in cocoa powder using the clean-up tandem assay column.

\begin{tabular}{|c|c|}
\hline False positive rate $^{*}$ & $10 \%$ \\
\hline False negative rate $^{\ddagger}$ & $2 \%$ \\
\hline Sensitivity $^{\ddagger}$ & $98 \%$ \\
\hline Specificity $^{\natural}$ & $90 \%$ \\
\hline Positive predictive value $^{\S}$ & $93 \%$ \\
\hline Negative predictive value $^{\#}$ & $97 \%$ \\
\hline Unreliability region $^{\sharp}$ & $1-2 \mu \mathrm{g} \mathrm{kg}^{-1}$ \\
\hline
\end{tabular}

\footnotetext{
${ }^{*}$ false positive rate $=(\mathrm{fp} / \mathrm{tn}+\mathrm{fp}) * 100,{ }^{\dagger}$ false negative rate $=(\mathrm{fn} / \mathrm{tp}+\mathrm{fn}) * 100,{ }^{*}$ sensitivity $=$ $(\mathrm{tp} / \mathrm{tp}+\mathrm{fn}) * 100,{ }^{\mathrm{I}}$ specificity $=(\mathrm{tn} / \mathrm{tn}+\mathrm{fp}) * 100,{ }^{\S}$ positive predictive value $=(\mathrm{tp} / \mathrm{tp}+\mathrm{fp}) * 100,{ }^{\#}$ negative predictive value $=(\operatorname{tn} / \mathrm{tn}+\mathrm{fn}) * 100$.
} 
Table IV. Concentration levels of ochratoxin A tested, with probabilities of positive, $\mathrm{P}(\mathrm{X})$, and negative, $\mathrm{N}(\mathrm{X})$, results calculated for each concentration level.

\begin{tabular}{|c|c|c|c|}
\hline Concentration, $\mu \mathrm{g} \mathrm{kg}^{-1}$ & Number of samples & $\mathrm{P}(\mathrm{X})$ & $\mathrm{N}(\mathrm{X})$ \\
\hline 0 & 20 & 0 & 100 \\
\hline 0.5 & 12 & 0 & 100 \\
\hline 1 & 20 & 25 & 75 \\
\hline 1.5 & 12 & 58 & 42 \\
\hline 2 & 14 & 100 & 0 \\
\hline 3 & 14 & 93 & 7 \\
\hline 4 & 14 & 100 & 0 \\
\hline 5 & 14 & 100 & 0 \\
\hline
\end{tabular}


Table V. OTA analysis of 10 different commercial cocoa powder samples available on the Belgian market.

\begin{tabular}{|c|c|c|}
\hline Number of commercial sample & $\begin{array}{l}\text { Qualitative result * (clean-up } \\
\text { tandem assay column) }\end{array}$ & $\begin{array}{c}\text { Quantitative result }\left(\mu \mathrm{g} \mathrm{kg}^{-1}\right)(\mathrm{LC}- \\
\text { MS/MS method) }\end{array}$ \\
\hline 1 & $--^{\dagger}$ & 0.0678 \\
\hline 2 & $-\cdots$ & 0.0831 \\
\hline 3 & $-\cdots$ & 0.0579 \\
\hline 4 & $-\cdots$ & 0.0553 \\
\hline 5 & $-\cdots$ & 0.0781 \\
\hline 6 & $V$ & 0.0654 \\
\hline 7 & $-\cdots$ & 0.0622 \\
\hline 8 & $\cdots$ & 0.0532 \\
\hline 9 & -- & 0.0774 \\
\hline 10 & $-\cdots$ & 0.0402 \\
\hline
\end{tabular}

$\dagger+=$ positive sample, $\geq 2 \mu \mathrm{g} \mathrm{kg}^{-1}$

- = negative sample, $<2 \mu \mathrm{g} \mathrm{kg}^{-1}$ 

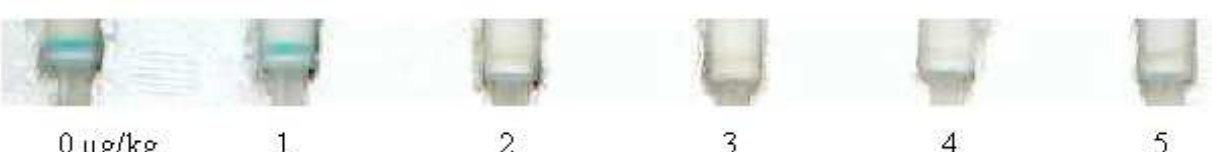

2

13

14

15

16

17

18

19

20

21

22

23

24

25

26

27

28

29

30

31

32

33

34

35

36

37

38

39

40

41

42

43

44

45

46

47

48

49

50

51

52

53

54

55

56

57

58

59

60

$170 \times 168 \mathrm{~mm}(96 \times 96 \mathrm{DPI})$

http://mc.manuscriptcentral.com/tfac Email: fac@tandf.co.uk 
1

2

3

4

5

6

7

8

9

10

11

12

13

14

15

16

17

18

19

20

21

22

23

24

25

26

27

28

29

30

31

32

33

34

35

36

37

38

39

40

41

42

43

44

45

46

47

48

49

50

51

52

53

54

55

56

57

58

59

60
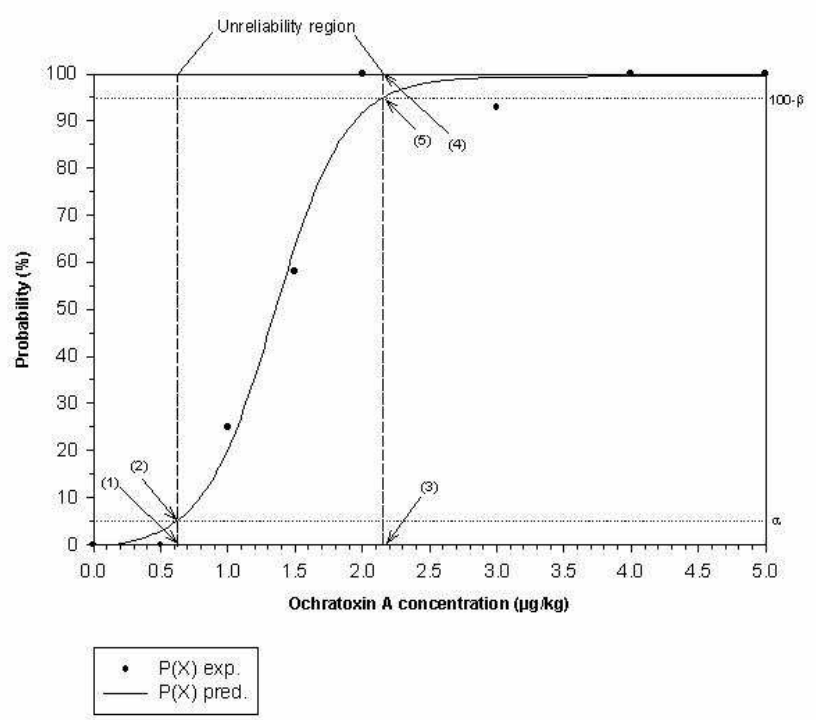

$237 \times 297 \mathrm{~mm}(96 \times 96 \mathrm{DPI})$

http://mc.manuscriptcentral.com/tfac Email: fac@tandf.co.uk 